\title{
Redox Activation of Alkene Ligands in Platinum Complexes with Non-innocent Ligands
}

\author{
Julie L. Boyer, ${ }^{\ddagger}$ Thomas R. Cundari, ${ }^{*, \dagger}$ Nathan J. DeYonker,${ }^{\dagger}$ Thomas B. Rauchfuss, ${ }^{*, \neq}$ \\ and Scott R. Wilson ${ }^{\ddagger}$ \\ Department of Chemistry and Center for Advanced Scientific Computing and Modeling \\ (CASCaM), University of North Texas, P.O. Box 305070, Denton, Texas 76203, and Department \\ of Chemistry, University of Illinois at Urbana-Champaign, 600 South Mathews Avenue, \\ Urbana, Illinois 61801
}

Received September 10, 2008

\begin{abstract}
The reactivity of metal olefin complexes with non-innocent ligands (NILs) was examined. Treatment of $\mathrm{PtCl}_{2}($ diene) with the deprotonated catechol or aminophenol ligands afforded the corresponding Pt(NIL)(diene) complexes. The

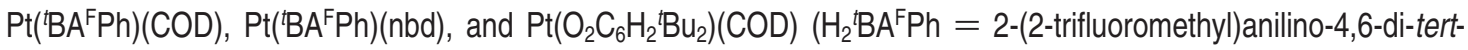
butylphenol, $\mathrm{H}_{2} \mathrm{O}_{2} \mathrm{C}_{6} \mathrm{H}_{2}{ }^{t} \mathrm{Bu}_{2}=3,5$-di-tert-butylcatechol) complexes were examined by cyclic voltammetry. Treatment of $\mathrm{Pt}\left({ }^{\mathrm{B}} \mathrm{BA}{ }^{\mathrm{F} P h}\right)(\mathrm{COD})$ or $\mathrm{Pt}\left({ }^{\mathrm{B}} \mathrm{BA}^{\mathrm{F}} \mathrm{Ph}\right)(\mathrm{nbd})$ with $\mathrm{AgPF}_{6}$ afforded the imino-semiquinones [Pt('BA $\left.\left.{ }^{\mathrm{F}} \mathrm{Ph}\right)(\mathrm{COD})\right] \mathrm{PF}_{6}$ or $\left[\mathrm{Pt}\left({ }^{\mathrm{B} A} \mathrm{~A}^{\mathrm{F} P h}\right)(\mathrm{nbd})\right] \mathrm{PF}_{6}$, respectively. The $\left.\left[\mathrm{Pt}^{\mathrm{t}} \mathrm{BA}^{\mathrm{F} P h}\right)(\mathrm{COD})\right]$ complex was unreactive toward nucleophiles, whereas the oxidized derivative, $\left[\mathrm{Pt}\left(\mathrm{BA} \mathrm{F}^{\mathrm{F}} \mathrm{Ph}\right)(\mathrm{COD})\right] \mathrm{PF}_{6}$, rapidly and stereospecifically added alkoxides at the carbon trans to the phenolate. The Pt('BAFPh)(COD), [Pt('BAF $\left.\left.{ }^{\mathrm{F}} \mathrm{Ph}\right)(\mathrm{COD})\right] \mathrm{PF} \mathrm{F}_{6}, \mathrm{Pt}\left(\mathrm{BA}^{\mathrm{F}} \mathrm{Ph}\right)\left(\mathrm{C}_{8} \mathrm{H}_{12} \mathrm{OMe}\right)$, and $\left[\mathrm{Cp}_{2} \mathrm{Co}\right][\mathrm{Pt}-$ ('BAFPh) $\left.\left(\mathrm{C}_{8} \mathrm{H}_{12} \mathrm{OMe}\right)\right]$ complexes were characterized crystallographically.
\end{abstract}

\section{Introduction}

Metal-centered oxidations are ubiquitous in organometallic transformations. A classic example of this is found in the Shilov system, where platinum(II) alkyls become susceptible to nucleophilic attack upon oxidation of the metal center. ${ }^{1}$ Metal-centered redox changes often lead to dramatic changes in the ligands. This effect is classically demonstrated by changes in the acidity of aquo ligands, ${ }^{2}$ but more recent work illustrates how redox changes can affect the reactivity of ligands of more direct relevance to homogeneous catalysis. For example, Tilset and co-workers estimate that a $1 \mathrm{e}^{-}$ oxidation increases the acidity of metal hydrides by as much as $10^{20} .{ }^{3}$ Such drastic changes portend the significant opportunities for exploiting the effects of redox on catalysis.

* To whom correspondence should be addressed. E-mail: rauchfuz@ uiuc.edu.

$\dagger$ University of North Texas.

University of Illinois at Urbana-Champaign.

(1) (a) Luinstra, G. A.; Wang, L.; Stahl, S. S.; Labinger, J. A.; Bercaw, J. E. Organometallics 1994, 13, 755-756. (b) Chen, G. S.; Labinger, J. A.; Bercaw, J. E. Proc. Natl. Acad. Sci. U.S.A. 2007, 104, 69156920.

(2) Wilkins, R. G. The Study of Kinetics and Mechanism of Reactions of Transition Metal Complexes; Wiley-VCH: Weinheim, Germany, 1991.

(3) Ryan, O. B.; Tilset, M.; Parker, V. D. J. Am. Chem. Soc. 1990, 112, 2618-2626.
Complementary to metal-centered redox, and more subtle, are ligand-centered redox reactions. ${ }^{4}$ Ligand-centered redox reactions are enabled through the use of non-innocent ligands (NILs), which are numerous and diverse in structure. Although NILs undergo redox changes remotely from the metal, the attendant changes in NIL donor properties affect the metal center and the other ligands. ${ }^{5}$ An excellent comparison of metal-centered versus ligand-centered redox changes is provided by Vlcek and co-workers. For the $\left[\mathrm{Mn}^{0}(\mathrm{CO})_{3}\left(\mathrm{O}_{2} \mathrm{C}_{6} \mathrm{H}_{2}{ }^{t} \mathrm{Bu}_{2}\right)\right]^{2-}$ and $\left[\mathrm{Mn}^{\mathrm{I}}(\mathrm{CO})_{3}\left(\mathrm{O}_{2} \mathrm{C}_{6} \mathrm{H}_{2}{ }^{t} \mathrm{Bu}_{2}\right)\right]^{-}$ complexes, the average $v_{\mathrm{CO}}$ value differs by $\sim 110 \mathrm{~cm}^{-1}$. In contrast, the ligand-centered oxidation of $\left[\mathrm{Mn}(\mathrm{CO})_{2}\left(\mathrm{P}(\mathrm{OEt})_{3}\right)_{2^{-}}\right.$ $\left.\left(\mathrm{O}_{2} \mathrm{C}_{6} \mathrm{H}_{2}{ }^{t} \mathrm{Bu}_{2}\right)\right]^{-}$shifts $v_{\mathrm{CO}}$ by $\sim 40 \mathrm{~cm}^{-1}$. ${ }^{6}$ Ligand-centered redox changes may prove more compatible with catalytic reactions, where gentle structural and energetic changes are more compatible with rapid turnover rates. ${ }^{7,8}$ The role of NILs is well-documented in bioinorganic chemistry. Ex-

(4) (a) Allgeier, A. M.; Mirkin, C. A. Angew. Chem., Int. Ed. 1998, 37, 895-908. (b) Blackmore, K. J.; Ziller, J. W.; Heyduk, A. F. Inorg. Chem. 2005, 44, 5559-5561.

(5) (a) Wada, T.; Fujihara, T.; Tomori, M.; Ooyama, D.; Tanaka, K. Bull. Chem. Soc. Jpn. 2004, 77, 741-749. (b) Hartl, F.; Vlcek, A., Jr Inorg. Chem. 1991, 30, 3048-3053.

(6) Hartl, F.; Stufkens, D. J.; Vlcek, A., Jr. Inorg. Chem. 1992, 31, 16871695. 
amples include modified phenols in galactose oxidase and in cytochrome $c$ oxidase and the porphyrinate in cytochrome P450. ${ }^{9}$

Although the coordination chemistry of NILs is longestablished, ${ }^{10}$ many of the prominent $\mathrm{M}-\mathrm{NIL}$ systems oxidize at fairly severe potentials. ${ }^{11-13}$ Furthermore, ligandcentered redox changes in $\mathrm{M}-\mathrm{NIL}$ complexes are known to induce aggregation, ${ }^{14}$ which quenches the coordinative unsaturation that is typically required for catalytic activity. For example, the unsaturated dithiolene derivatives of $\mathrm{CpCo}^{\text {III }}$ and (arene) $\mathrm{Ru}^{\text {II }}$ dimerize upon oxidation. ${ }^{15}$ The $\mathrm{N}$-substituted amidophenolate ligands popularized by Wieghardt et al. resolve the deficiencies with traditional NILs, offering both mild redox potentials and steric bulk that inhibits redoxinduced aggregation. ${ }^{13,16-18}$

Studies of the role of NILs in other areas of organometallic chemistry are accelerating. ${ }^{19,20}$ Despite these advances, the influence of redox poise of an NIL on alkenes remains underdeveloped. Metal alkene complexes with NILs have been reported, but well-defined systems with fully characterized redox partners have not been

(7) (a) Muckerman, J. T.; Polyansky, D. E.; Wada, T.; Tanaka, K.; Fujita, E. Inorg. Chem. 2008, 47, 1787-1802. (b) Abakumov, G. A.; Poddel'sky, A. I.; Grunova, E. V.; Cherkasov, V. K.; Fukin, G. K.; Kurskii, Y. A.; Abakumova, L. G. Angew. Chem., Int. Ed. 2005, 44, 2767-2771. (c) Blackmore, K. J.; Lal, N.; Ziller, J. W.; Heyduk, A. F. J. Am. Chem. Soc. 2008, 130, 2728-2729. (d) Lorkovic, I. M.; Duff, R. R., Jr.; Wrighton, M. S. J. Am. Chem. Soc. 1995, 117, 3617-3618. (e) Lorkovic, I. M.; Wrighton, M. S.; Davis, W. M. J. Am. Chem. Soc. 1994, 116, 6220-6228.

(8) Ringenberg, M. R.; Kokatam, S. L.; Heiden, Z. M.; Rauchfuss, T. B. J. Am. Chem. Soc. 2008, 130, 788-789.

(9) (a) Stubbe, J.; van der Donk, W. A. Chem. Rev. 1998, 98, 705-762. (b) Chaudhuri, P.; Wieghardt, K. Prog. Inorg. Chem. 2001, 50, 151216.

(10) (a) Kaim, W. Coord. Chem. Rev. 1987, 76, 187-235. (b) Pierpont, C. G.; Lange, C. W. Prog. Inorg. Chem. 1994, 41, 331-442. (c) Zanello, P.; Corsini, M. Coord. Chem. Rev. 2006, 250, 2000-2022. (d) Stiefel, E. I., Karlin, K. D., Eds. Progress in Inorganic Chemistry; Wiley: New York, 2003; Vol. 52. (e) Fourmigue, M. Coord. Chem. Rev. 1998, 178-180, 823-864.

(11) Bevilacqua, J. M.; Zuleta, J. A.; Eisenberg, R. Inorg. Chem. 1993, 32, 3689-3693.

(12) Don, M.-J.; Yang, K.; Bott, S. G.; Richmond, M. G. J. Chem. Crystallogr. 1996, 26, 335-340.

(13) Ghosh, P.; Begum, A.; Herebian, D.; Bothe, E.; Hildenbrand, K.; Weyhermüller, T.; Wieghardt, K. Angew. Chem., Int. Ed. 2003, 42, 563-567.

(14) (a) Don, M.-J.; Yang, K.; Bott, S. G.; Richmond, M. G. J. Organomet. Chem. 1997, 544, 15-21. (b) Mitsumi, M.; Goto, H.; Umebayashi, S.; Ozawa, Y.; Kobayashi, M.; Yokoyama, T.; Tanaka, H.; Kuroda, S.; Toriumi, K. Angew. Chem., Int. Ed. 2005, 44, 4164-4168. (c) Pap, J. S.; Benedito, F. L.; Bothe, E.; Bill, E.; George, S. D.; Weyhermüller, T.; Wieghardt, K. Inorg. Chem. 2007, 46, 4187-4196.

(15) (a) Nomura, M.; Fourmigue, M. J. Organomet. Chem. 2007, 692 , 2491-2499. (b) Nomura, M.; Fujii, M.; Fukuda, K.; Sugiyama, T.; Yokoyama, Y.; Kajitani, M. J. Organomet. Chem. 2005, 690, 16271637.

(16) Chaudhuri, P.; Verani, C. N.; Bill, E.; Bothe, E.; Weyhermüller, T.; Wieghardt, K. J. Am. Chem. Soc. 2001, 123, 2213-2223.

(17) Sun, X.; Chun, H.; Hildenbrand, K.; Bothe, E.; Weyhermüller, T.; Neese, F.; Wieghardt, K. Inorg. Chem. 2002, 41, 4295-4303.

(18) Bill, E.; Bothe, E.; Chaudhuri, P.; Chlopek, K.; Herebian, D.; Kokatam, S.; Ray, K.; Weyhermüller, T.; Neese, F.; Wieghardt, K. Chem.-Eur. J. 2005, 11, 204-224.

(19) (a) Haneline, M. R.; Heyduk, A. F. J. Am. Chem. Soc. 2006, 128 8410-8411. (b) Wang, K.; Stiefel, E. I. Science 2001, 291, 106-109.

(20) Bouwkamp, M. W.; Bowman, A. C.; Lobkovsky, E.; Chirik, P. J. J. Am. Chem. Soc. 2006, 128, 13340-13341. described. ${ }^{11,12,20,21}$ In this work, we probe the influence of the amidophenolate NILs on the coordination properties of alkenes. Metal alkene complexes have broad importance, including economically significant processes such as Reppe chemistry and Wacker oxidation, along with innumerable stoichiometric reactions. ${ }^{22}$

For this work, we selected the non-innocent ligand 2-(2trifluoromethyl)anilino-4,6-di-tert-butylphenol $\left(\mathrm{H}_{2}{ }^{t} \mathrm{BA}{ }^{\mathrm{F}} \mathrm{Ph}\right)$. Since amidophenolates are derived from $t$-Bu-substituted catecholates, the resulting complexes exhibit enhanced solubility in noncoordinating solvents that facilitates the isolation of reactive radicals. In this ligand, the amine is functionalized with a 2-trifluoromethylphenyl group, and the plane of this aryl ring is perpendicular to the MON plane of the chelate ring. This ligand has been shown to form homoleptic complexes of the type $\left[\mathrm{M}\left({ }^{t} \mathrm{BA}{ }^{\mathrm{F}} \mathrm{Ph}\right)_{2}\right]^{z}(\mathrm{M}=\mathrm{Co}$, $\mathrm{Ni}$, and Pd). ${ }^{18,23}$ Recently, we have isolated the mixed-ligand, organometallic complex, $\mathrm{Cp} * \mathrm{Ir}^{\mathrm{t}} \mathrm{BA}{ }^{\mathrm{F}} \mathrm{Ph}$, and its redox-related partner. ${ }^{8}$

\section{Results and Discussion}

Synthesis of $\mathbf{P t}$-Diene-Amidophenolate Complexes. Our targeted case was the 1,5-cyclooctadiene (COD) complex, $\mathrm{Pt}\left({ }^{\mathrm{B}} \mathrm{BA}^{\mathrm{F}} \mathrm{Ph}\right)(\mathrm{COD})$ (1). The complex forms in excellent yield by treating $\mathrm{PtCl}_{2}(\mathrm{COD})$ with the sodium salt of the ligand. Unusual for platinum olefin complexes, the compound is intensely orange. Otherwise, it exhibits conventional spectroscopic properties. The NMR spectrum confirms the structural rigidity of the $N$-aryl substituent: the slowed rotation of the trifluoromethylphenyl group is manifested in diastereotopic vinylic signals for the protons cis to the $\mathrm{N}$-substituted amido at $\delta 4.10$ and 4.36. Mass spectrometry and X-ray crystallography also confirmed the formation of the $\mathrm{Pt}\left({ }^{t} \mathrm{BA}^{\mathrm{F}} \mathrm{Ph}\right)(\mathrm{COD})$.

Related to $\mathbf{1}$, the norbornadiene complex, $\mathrm{Pt}\left({ }^{t} \mathrm{BA}{ }^{\mathrm{F}} \mathrm{Ph}\right)$ (nbd) (2), was also prepared. We were, however, unable to obtain analogous Pd complexes: treatment of $\mathrm{PdCl}_{2}(\mathrm{COD})$ with the freshly prepared $\mathrm{Na}_{2}{ }^{t} \mathrm{~B} \mathrm{~A}^{\mathrm{F}} \mathrm{Ph}$ afforded a metallic precipitate, as well as the previously reported $\mathrm{Pd}\left({ }^{t} \mathrm{BA}{ }^{\mathrm{F}} \mathrm{Ph}\right)_{2}{ }^{23}$ The catecholate analogues, $\mathrm{Pt}\left(\mathrm{O}_{2} \mathrm{C}_{6} \mathrm{H}_{2}{ }^{t} \mathrm{Bu}_{2}\right)(\mathrm{COD})(3)$ and $\mathrm{Pt}\left(\mathrm{O}_{2} \mathrm{C}_{6} \mathrm{H}_{4}\right)(\mathrm{COD})$ (4), were also prepared as reference compounds.

(21) (a) Calvo, M. A.; Manotti Lanfredi, A. M.; Oro, L. A.; Pinillos, M. T.; Tejel, C.; Tiripicchio, A.; Ugozzoli, F. Inorg. Chem. 1993, 32, 11471152. (b) Lange, C. W.; Pierpont, C. G. J. Am. Chem. Soc. 1992, 114, 6582-6583. (c) Razuvaev, G. A.; Abakumov, G. A.; Teplova, I. A.; Shalnova, K. G.; Cherkasov, V. K. Inorg. Chim. Acta 1981, 53, L267-L269. (e) Cummings, S. D.; Eisenberg, R. Inorg. Chem. 1995, 34, 2007-2014. (f) Spikes, G. H.; Bill, E.; Weyhermüller, T.; Wieghardt, K. Angew. Chem., Int. Ed. 2008, 47, 2973-2977. (g) Taquet, J.-p.; Siri, O.; Braunstein, P.; Welter, R. Inorg. Chem. 2006, $45,4668-4676$.

(22) (a) Pearson, A. J. In Comprehensive Organometallic Chemistry II; Abel, E. W., Stone, F. G. A., Wilkinson, G., Eds.; Pergamon Press: Oxford, U.K., 1995; Vol. 12, pp 637-683. (b) Behr, A. Ullmann's Encyclopedia of Industrial Chemistry, 7th ed.; John Wiley \& Sons, Inc.: New York, 2008. (c) McDaniel, K. F. In Comprehensive Organometallic Chemistry II; Abel, E. W., Stone, F. G. A., Wilkinson, G., Eds.; Pergamon Press: Oxford, U.K., 1995; Vol. 12, pp 601-622.

(23) Kokatam, S.; Weyhermüller, T.; Bothe, E.; Chaudhuri, P.; Wieghardt, K. Inorg. Chem. 2005, 44, 3709-3717. 
Table 1. Electrochemical Data ${ }^{a}$

\begin{tabular}{|c|c|c|}
\hline complex & $E_{1 / 2}^{1}$ & $E_{1 / 2}^{2}$ \\
\hline $\mathrm{Pt}\left({ }^{t} \mathrm{~B} A^{\mathrm{F}} \mathrm{Ph}\right)(\mathrm{COD})$ & 0.31 & 1.18 \\
\hline $\mathrm{Pt}\left({ }^{t} \mathrm{BA}{ }^{\mathrm{F}} \mathrm{Ph}\right)(\mathrm{nbd})(2)$ & 0.40 & 1.13 \\
\hline $\mathrm{Pt}\left(\mathrm{O}_{2} \mathrm{C}_{6} \mathrm{H}_{2}{ }^{t} \mathrm{Bu}_{2}\right)(\mathrm{COD})(\mathbf{3})$ & 0.67 & 1.21 \\
\hline $\mathrm{Pt}\left(\mathrm{O}_{2} \mathrm{C}_{6} \mathrm{H}_{4}\right)(\mathrm{COD})(4)$ & 0.84 (irrev) & 1.17 (irrev) \\
\hline $\mathrm{Pt}\left({ }^{t} \mathrm{BA}^{\mathrm{F}} \mathrm{Ph}\right)\left(\mathrm{C}_{8} \mathrm{H}_{12} \mathrm{OMe}\right)(1 \mathrm{OMe})$ & -0.45 & 0.55 \\
\hline
\end{tabular}
$\mathrm{CH}_{2} \mathrm{Cl}_{2}$ solutions reported as $\mathrm{V}$ versus $\mathrm{Ag} / \mathrm{AgCl}$.
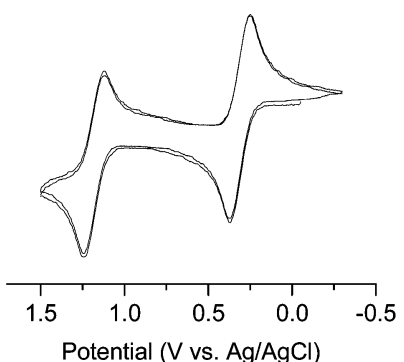

Potential (V vs. Ag/AgCl)

Figure 1. Cyclic voltammogram of $\mathbf{1}$ (left) and $1 \mathrm{OMe}$ (right) recorded at scan rates of $50 \mathrm{mV} / \mathrm{s}$ in $0.1 \mathrm{M} \mathrm{NBu}_{4} \mathrm{PF}_{6}$ solutions in $\mathrm{CH}_{2} \mathrm{Cl}_{2}$.

Complexes 1-4 were examined by cyclic voltammetry $(\mathrm{CV})$ as a prelude to chemical oxidations and to benchmark the influence of ${ }^{t} \mathrm{BA}^{\mathrm{F}} \mathrm{Ph}^{2-}$ relative to standard catecholate ligands (Table 1). Complex 1 oxidizes reversibly at 0.31 and $1.18 \mathrm{~V}$ versus $\mathrm{Ag} / \mathrm{AgCl}$ (Figure 1). The norbornadiene complex 2 also undergoes two reversible oxidations at the similar potentials of 0.40 and $1.13 \mathrm{~V}$. These data provide rare evidence for the increased donor ability of COD versus the other common chelating diene, nbd. Complex $\mathbf{3}$, containing the substituted catecholate, oxidizes reversibly, as seen for $\mathbf{1}$, but at a potential that is $350 \mathrm{mV}$ more positive. The complex of the unsubstituted catecholate $\mathbf{4}$ oxidizes irreversibly and at still more positive potentials. ${ }^{12}$ The complex $\mathrm{Pt}(\mathrm{mnt})(\mathrm{COD})(\mathrm{mnt}=$ maleonitriledithiolate $)$ displays no observable oxidation events within the same potential range. ${ }^{11}$
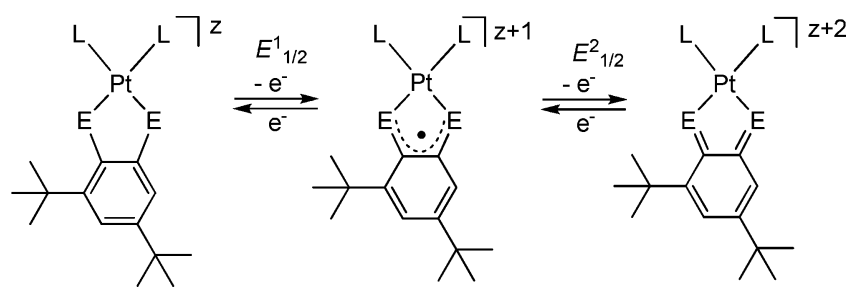

Chemical Oxidation of Diolefin Complexes. Oxidation of a THF solution of $\mathbf{1}$ with $\mathrm{AgPF}_{6}$ gave the dark orangecolored product, $\left[\mathrm{Pt}\left({ }^{t} \mathrm{BA}{ }^{\mathrm{F}} \mathrm{Ph}\right)(\mathrm{COD})\right] \mathrm{PF}_{6}\left([\mathbf{1}] \mathrm{PF}_{6}\right)$. This robust species exhibited a well-resolved isotropic EPR spectrum centered at $g_{\text {iso }}=1.9984$, a value consistent with a ligandcentered radical, indicative of an imino-semiquinone coligand. ${ }^{17}$ Reduction of a solution of $[1] \mathrm{PF}_{6}$ with $\mathrm{NEt}_{3}$ regenerated 1. The nbd derivative, $\left[\mathrm{Pt}\left({ }^{\mathrm{t}} \mathrm{BA}^{\mathrm{F}} \mathrm{Ph}\right)(\mathrm{nbd})\right] \mathrm{PF}_{6}$ ([2] $\mathrm{PF}_{6}$ ), was prepared similarly. Complexes $\mathbf{1}^{+/ 0}$ and $\mathbf{2}^{+/ 0}$ represent rare examples of alkene M-NIL complexes isolated in two redox states.

The salt $[1] \mathrm{PF}_{6}$ and its precursor were further characterized by X-ray crystallography (Figure 2 and Table 2). In 1, the carbon-carbon distances within the amidophenolate ring
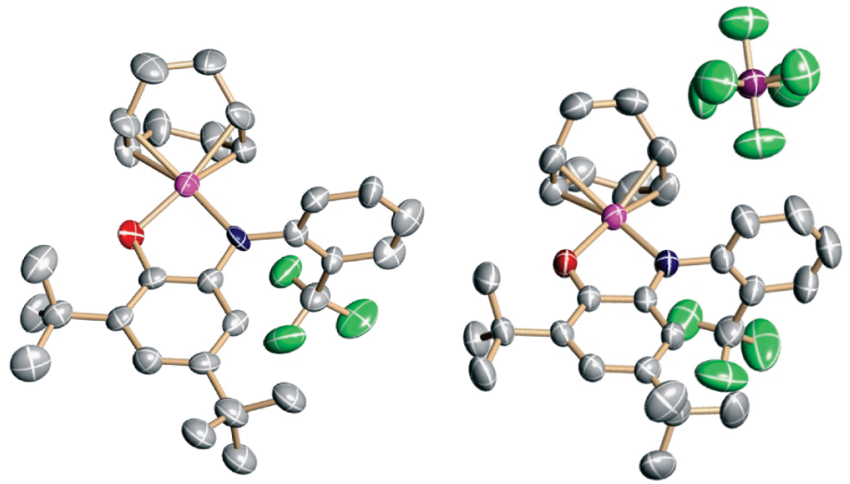

Figure 2. Molecular structure of $\mathbf{1}$ (left) and [1] $\mathrm{PF}_{6}$ (right) with thermal ellipsoids drawn at 50\%. Color scheme: Pt (pink), $\mathrm{P}$ (purple), $\mathrm{F}$ (green), $\mathrm{O}$ (red), $\mathrm{N}$ (blue), and $\mathrm{C}$ (gray). Hydrogen atoms were omitted for clarity.

Table 2. Selected Bond Lengths $(\AA)$ for $1,[1] \mathrm{PF}_{6}, 10 \mathrm{Me}$, and $\mathrm{Cp}_{2} \mathrm{Co}[1 \mathrm{OMe}]$<smiles>[R]NP1(C)(C)OC2CCCCC2O1</smiles>

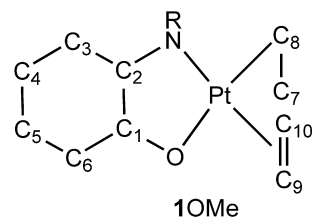

\begin{tabular}{llllc}
\hline \multicolumn{1}{c}{ bond } & \multicolumn{1}{c}{$\mathbf{1}^{a}$} & {$[\mathbf{1}] \mathrm{PF}_{6}$} & $\mathbf{1 O M e}^{a}$ & $\mathrm{Cp}_{2} \mathrm{Co}[\mathbf{1 O M e}]^{a}$ \\
\hline $\mathrm{C} 1-\mathrm{C} 2$ & $1.398(17)$ & $1.448(3)$ & $1.445(14)$ & $1.413(15)$ \\
$\mathrm{C} 2-\mathrm{C} 3$ & $1.391(16)$ & $1.415(4)$ & $1.416(14)$ & $1.399(14)$ \\
$\mathrm{C} 3-\mathrm{C} 4$ & $1.386(17)$ & $1.352(4)$ & $1.357(15)$ & $1.395(15)$ \\
$\mathrm{C} 4-\mathrm{C} 5$ & $1.387(18)$ & $1.437(4)$ & $1.435(15)$ & $1.383(15)$ \\
$\mathrm{C} 5-\mathrm{C6}$ & $1.383(16)$ & $1.370(4)$ & $1.366(15)$ & $1.393(15)$ \\
$\mathrm{C} 6-\mathrm{C} 1$ & $1.399(17)$ & $1.417(3)$ & $1.433(15)$ & $1.389(16)$ \\
$\mathrm{C} 2-\mathrm{N}$ & $1.376(16)$ & $1.341(3)$ & $1.370(13)$ & $1.415(14)$ \\
$\mathrm{C} 1-\mathrm{O}$ & $1.335(15)$ & $1.316(3)$ & $1.283(12)$ & $1.392(13)$ \\
$\mathrm{Pt}-\mathrm{N}$ & $1.973(10)$ & $2.020(2)$ & $2.024(9)$ & $2.003(9)$ \\
$\mathrm{Pt}-\mathrm{O}$ & $1.961(8)$ & $2.0115(19)$ & $2.117(7)$ & $2.089(8)$ \\
$\mathrm{Pt}-\mathrm{C} 7$ & $2.128(16)$ & $2.162(3)$ & & \\
$\mathrm{Pt}-\mathrm{C} 8$ & $2.155(14)$ & $2.145(3)$ & $2.098(12)$ & $2.067(13)$ \\
$\mathrm{C} 8-\mathrm{C} 7$ & $1.380(2)$ & $1.388(6)$ & $1.503(16)$ & $1.467(19)$ \\
$\mathrm{Pt}-\mathrm{C} 9$ & $2.144(15)$ & $2.181(3)$ & $2.110(11)$ & $2.085(11)$ \\
$\mathrm{Pt}-\mathrm{C} 10$ & $2.160(12)$ & $2.192(3)$ & $2.131(11)$ & $2.092(11)$ \\
$\mathrm{C} 10-\mathrm{C} 9$ & $1.402(19)$ & $1.390(5)$ & $1.410(15)$ & $1.396(17)$
\end{tabular}

${ }^{a}$ Data for only one crystallographically independent molecule are given; the two molecules are structurally similar.

range from 1.377 to $1.402 \AA$, consistent with the unperturbed aromaticity of the phenylene group. For the oxidized complex [1] $\mathrm{PF}_{6}$, these $\mathrm{C}-\mathrm{C}$ distances were more disparate, ranging from 1.352(4) to $1.437(4) \AA$. Relative to $\mathbf{1},[1] \mathrm{PF}_{6}$ exhibits elongated $\mathrm{Pt}-\mathrm{O}(1.961(8)$ to $2.0115(19) \AA)$ and $\mathrm{Pt}-\mathrm{N}$ distances (1.973(10) to 2.020(2) $\AA$ ). The $\mathrm{Pt}$-alkene distances barely changed (less than $0.04 \AA$ ) upon oxidation of $\mathbf{1}$. In contrast, Bennett showed the $\mathrm{Ru}-$ alkene distances in $[\mathrm{Ru}-$ (acac) $\left.{ }_{2}\left(o-\mathrm{CH}_{2}=\mathrm{CHC}_{6} \mathrm{H}_{4}-2-\mathrm{NMe}_{2}\right)\right]^{0 /+}$ were $0.06-0.08 \AA$ longer in the $\mathrm{Ru}(\mathrm{III})$ derivative. ${ }^{24}$ The observed lengthening of $\mathrm{Pt}$-ligand bonds in 1 versus [1] $\mathrm{PF}_{6}$ were reproduced in the DFT-calculated structures of $\mathbf{1}$ and $\mathbf{1}^{+}: \Delta_{\mathrm{PtO}} \sim 0.03 \AA$, $\Delta_{\mathrm{PtN}} \sim 0.05 \AA$, and $\Delta_{\mathrm{PtC}} \sim 0.02-0.04 \AA$. Plotting the HOMO of 1 ( Figure 3) shows it to be Pt-O/N/C bonding, with a smaller contribution from the olefin carbons of the COD than from the $\mathrm{O}$ and $\mathrm{N}$ atoms of ${ }^{t} \mathrm{BA}{ }^{\mathrm{F}} \mathrm{Ph}$. Additionally, for $\mathbf{1}$, the $\mathrm{C}-\mathrm{C}$ bond lengths of the amidophenolate ring are calculated

(24) Bennett, M. A.; Heath, G. A.; Hockless, D. C. R.; Kovacik, I.; Willis, A. C. J. Am. Chem. Soc. 1998, 120, 932-941. 


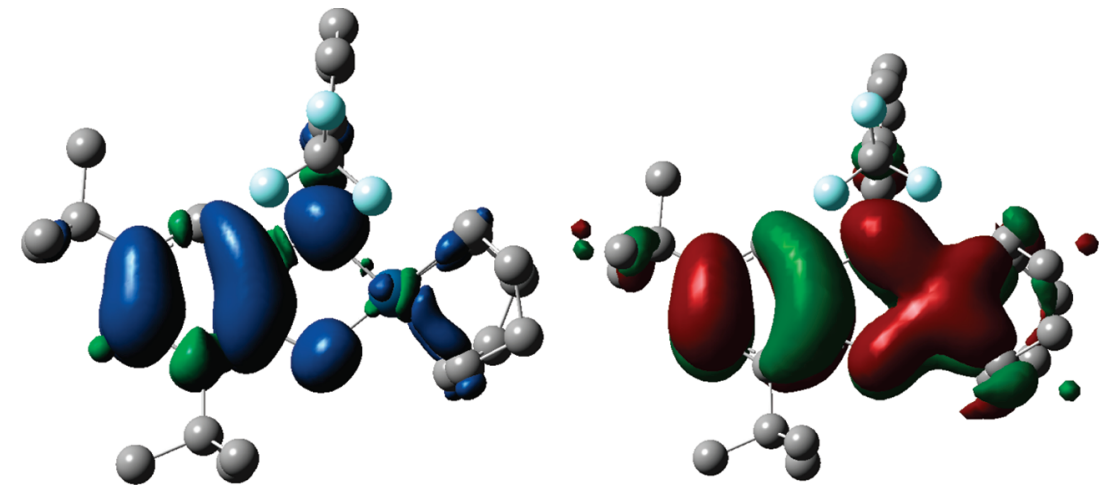

Figure 3. Calculated spin density for $\mathbf{1}^{+}$(isovalue $=0.0008$ ), left. Plot of the calculated HOMO of $\mathbf{1}$ (isovalue $=0.02$ ), right. Hydrogen atoms were omitted for clarity.
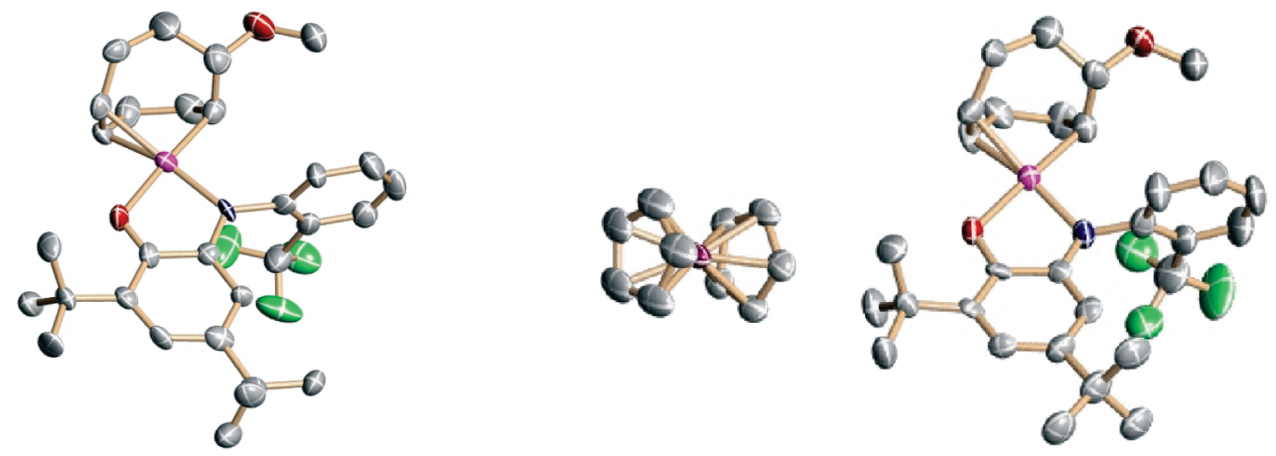

Figure 4. Molecular structure of $1 \mathrm{OMe}$ (left) and $\mathrm{Cp}_{2} \mathrm{Co}[1 \mathrm{OMe}]$ (right) with thermal ellipsoids drawn at 50\%. Color scheme: $\mathrm{Pt}$ (pink), Co (purple), $\mathrm{F}$ (green), $\mathrm{O}$ (red), $\mathrm{N}$ (blue), and $\mathrm{C}$ (gray). Hydrogen atoms were omitted for clarity.

Scheme 1

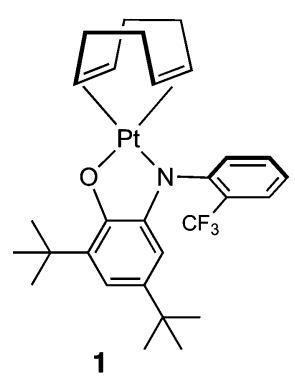

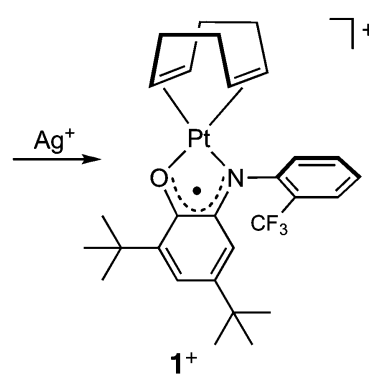

$1^{+}$

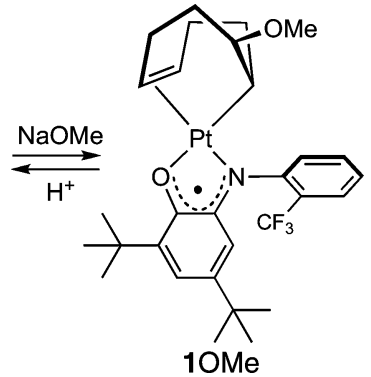

to be in a narrow range, 1.39-1.41 $\AA$, suggestive of aromaticity, whereas for $\mathbf{1}^{+}$, the $\mathrm{C}-\mathrm{C}$ range of $1.38-1.45$ $\AA$ supports an imino-semiquinone description. Again, this computed result mimics the crystallographic analysis of $\mathbf{1}$ and $[1] \mathrm{PF}_{6}$. Finally, plotting the spin density (Figure 3 ) of $\mathbf{1}^{+}$shows the majority of the electron density to be on the imino-semiquinone ring, consistent with the EPR spectral assignment (vide supra). The experimental and calculated data, taken together, support the formulation of [1] $\mathrm{PF}_{6}$ as a ligand-centered radical.

Reactions of $\mathbf{P t}$-Imino-semiquinone-Alkene Complexes. In $[1] \mathrm{PF}_{6}$, the diolefin is activated toward nucleophilic attack. Treatment of solutions of $[\mathbf{1}] \mathrm{PF}_{6}$ with $\mathrm{NaOR}(\mathrm{R}=$ Et or Me) efficiently afforded the alkoxide adducts (Scheme 1). The nucleophilic addition proved reversible: treatment of $10 \mathrm{Me}$ with $\mathrm{HPF}_{6}$ regenerated [1] $\mathrm{PF}_{6}$. The isotropic EPR spectrum of $10 \mathrm{Me}$ was simulated for a single species with $g_{\text {iso }}=2.009$, indicative of regioselective addition of the methoxide. The cyclic voltammogram of $1 \mathrm{OMe}$ in $\mathrm{CH}_{2} \mathrm{Cl}_{2}$ solution displays one oxidation and one reduction, at $E_{1 / 2}=$

0.55 and $-0.45 \mathrm{~V}$, respectively (Figure 1). The DFToptimized $\mathrm{C}-\mathrm{C}$ bond lengths of the aromatic ring of $10 \mathrm{Me}$ range from 1.38 to $1.46 \AA$, consistent with the ligandcentered, imino-semiquinone formulation.

In $10 \mathrm{Me}$, the nucleophile is situated at an exo position, trans to the phenolate (Figure 4 ). As in $[1] \mathrm{PF}_{6}, 10 \mathrm{Me}$ features an imino-semiquinone ligand, as indicated by the pattern of bond distances within the chelating N,O ligand. Compared to $[1] \mathrm{PF}_{6}$, the $\mathrm{C}-\mathrm{N}$ distances are elongated (1.341(3) to $1.370(13) \AA$ ) and the $\mathrm{C}-\mathrm{O}$ distances are shortened (1.316(3) to $1.283(12) \AA$ ) in $10 \mathrm{Me}$. The $\mathrm{Pt}-\mathrm{O}$ distance is most strongly affected by the addition of the methoxide, with an increase from 2.0115(19) to 2.117(7) $\AA$. These changes in bond length between $[1] \mathrm{PF}_{6}$ and $\mathbf{1 O M e}$ are reflected both in direction and in magnitude upon comparison of the DFToptimized structures of $\mathbf{1}^{+}$and $10 \mathrm{Me}$, although the elongation of the $\mathrm{C}-\mathrm{N}$ bond is modest, $\delta_{\mathrm{CN}}<0.01 \AA$, in the calculations.

As indicated by the voltammetry measurements, $10 \mathrm{Me}$ can be readily reduced. Treatment of $1 \mathrm{OMe}$ with $\mathrm{Cp}_{2} \mathrm{Co}$ gave 


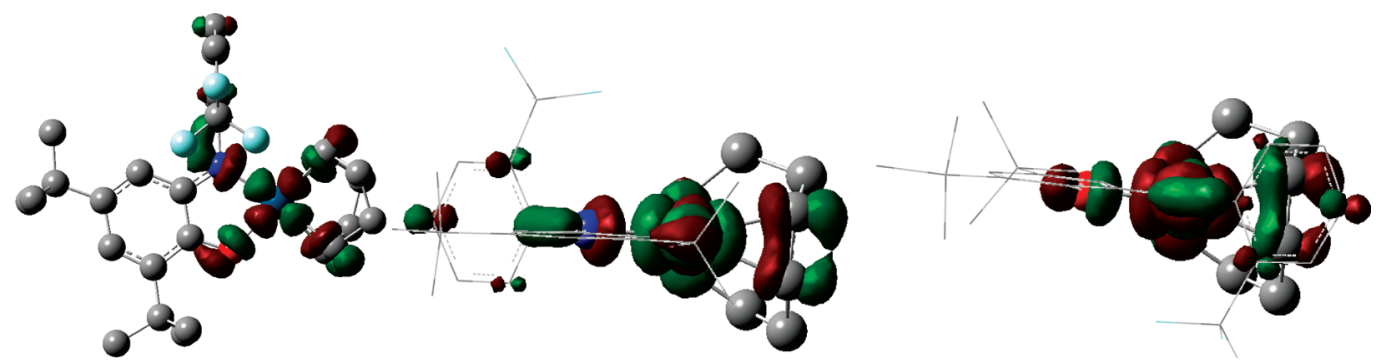

Figure 5. Left: Kohn-Sham LUMO of $\mathbf{1}^{+}$, orthogonal to the square plane of $\mathrm{Pt}_{1} \mathrm{CF}_{3}$ coming out toward the reader (hydrogen atoms omitted for clarity). Middle: KS LUMO of $\mathbf{1}^{+}$viewed along the $\mathrm{Pt}-\mathrm{O}$ bond. Note only a small polarization of the $\mathrm{C}=\mathrm{C} \pi$ portion of the orbital (right-hand side of figure, $\mathrm{BA}^{\mathrm{F}} \mathrm{Ph}$ ligand shown in wireframe for clarity). Right: $\mathrm{KS}$ LUMO of $\mathbf{1}^{+}$viewed along the $\mathrm{Pt}-\mathrm{N}$ bond. Note only a small polarization of the $\mathrm{C}=\mathrm{C} \pi$ portion of the orbital (right-hand side of figure, $\mathrm{BA} \mathrm{F}^{\mathrm{Ph}}$ ligand shown in wireframe for clarity).

the anionic derivative that was characterized crystallographically as its $\mathrm{Cp}_{2} \mathrm{Co}^{+}$salt. The anion in $\mathrm{Cp}_{2} \mathrm{Co}[1 \mathrm{OMe}]$ retains the stereochemistry of its precursor. Bond distances indicate that the complex contains an amidophenolate, not an iminosemiquinone ligand. Thus, reduction results in an increase in both the $\mathrm{C}-\mathrm{N}(1.370(13)$ to $1.415(14) \AA$ ) and $\mathrm{C}-\mathrm{O}$ bonds

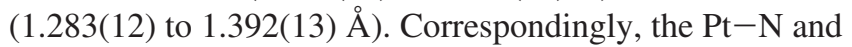
$\mathrm{Pt}-\mathrm{O}$ distance decreased. Distances within the phenolate ring are again consistent with aromaticity. Of the four structures, this anionic complex displays the shortest $\mathrm{Pt}-\mathrm{C}_{\text {alkene }}$ distances (2.085(11) and 2.092(11) ^). The NMR spectrum of $\mathrm{Cp}_{2} \mathrm{Co}[1 \mathrm{OMe}]$ is broadened due to paramagnetic impurities, but sufficiently well resolved to demonstrate that a single isomer is present, again confirming that the methoxide adds stereospecifically. In view of the isolability of $\mathrm{Cp}_{2} \mathrm{Co}[1 \mathrm{OMe}]$, we attempted the reaction of $\mathbf{1}$ with $\mathrm{NaOMe}$, but no reaction occurred.

DFT Calculations. The combination of spectroscopy, electrochemistry, and reactivity displayed by $\mathrm{Pt}\left({ }^{t} \mathrm{BA}{ }^{\mathrm{F}} \mathrm{Ph}\right)$ complexes of diolefins reveals a rich chemistry that is potentially tunable via the use of appropriate NILs. Of particular interest, in the context of catalysis, is the regiospecificity of nucleophilic addition that is observed upon oxidation of the starting materials. Simulations, first sought to assess if kinetic or thermodynamic discrimination led to the observed product, 1OMe. On the basis of a natural population analysis (NPA), little difference in calculated atomic charges is seen among the alkene carbon atoms in $\mathbf{1}$ and $\mathbf{1}^{+}\left(q\left(\mathbf{C}_{\mathrm{ol}}\right)=-0.29\right.$ to $-0.31 \mathrm{e}^{-}$for the four olefin carbons in 1 , and $q\left(\mathrm{C}_{\mathrm{ol}}\right)=-0.24$ to $-0.26 \mathrm{e}^{-}$for the four olefin carbons in $\mathbf{1}^{+}$). Furthermore, the frontier orbitals of $\mathbf{1}^{+}$, in particular, low-energy unoccupied orbitals with orbital character on the COD double bonds in $\mathbf{1}^{+}$, were analyzed to assess whether the regiochemistry of methoxide addition to $\mathbf{1}^{+}$is orbitally controlled. Only small polarization of the $\mathrm{C}=\mathrm{C}$ $\pi$ orbitals of the COD orbitals could be discerned (Figure 5). Hence, we focused on the possibility that the regiochemistry of methoxide addition to $\mathbf{1}^{+}$was dictated by thermodynamic considerations.

One further point of potential relevance to the regiochemistry of methoxide addition concerns the NPA-calculated atomic charges that change very little for both $\mathrm{Pt}$ and $\mathrm{O}$ (of ${ }^{t} \mathrm{BA}^{\mathrm{F}} \mathrm{Ph}$ ) (by $<0.05 \mathrm{e}^{-}$upon oxidation of $\mathbf{1}$ to $\mathbf{1}^{+}$). The NPA atomic charge on the nitrogen of ${ }^{t} \mathrm{BA}{ }^{\mathrm{F}} \mathrm{Ph}$, however, changes the most substantially upon oxidation of $\mathbf{1}\left(-0.68 \mathrm{e}^{-}\right)$to $\mathbf{1}^{+}$ $\left(-0.55 \mathrm{e}^{-}\right)$. This change is consistent with the orbital makeup

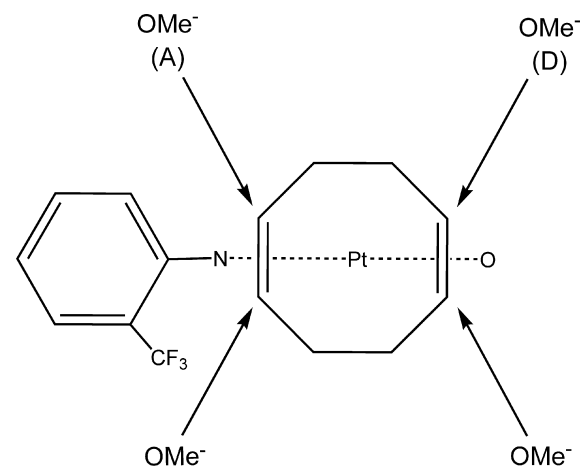

(B)

(C)

Figure 6. Depiction of the four possible regiochemistries for methoxide addition of $\mathbf{1}^{+}$to yield 1 OMe. COD is coming out toward the reader, whereas ${ }^{t} \mathrm{BA}{ }^{\mathrm{F}} \mathrm{Ph}$ goes into the plane. Different isomers arising from different olefin carbons, to which methoxide is added, are indicated in parentheses. Observed product $1 \mathrm{OMe}$ corresponds to addition product $\mathbf{A}$.

Table 3. Relative Calculated Free Energies (in $\mathrm{kcal} \mathrm{mol}^{-1}$ ) of the Various Isomers of 1OMe

\begin{tabular}{ccccc}
\hline & $\mathrm{A}$ & $\mathrm{B}$ & $\mathrm{C}$ & $\mathrm{D}$ \\
\hline$\Delta G\left(\mathrm{kcal} \mathrm{mol}^{-1}\right)$ & 0.00 & 19.62 & 9.59 & 5.35
\end{tabular}

of the HOMO of 1 (Figure 3), which has a $\pi$ orbital located on the ${ }^{t} \mathrm{BA}^{\mathrm{F}} \mathrm{Ph}$ ligand, more $\mathrm{N}$ than $\mathrm{O}$ character, and less $\mathrm{C}=\mathrm{C}$ character. Also, we note the asymmetry in the spin density (left-hand side of Figure 3 ) of $\mathbf{1}^{+}$. Hence, we cannot discount a subtle trans effect (i.e., a transition-state versus a ground-state effect) mediated by the oxidation of ${ }^{t} \mathrm{BA}^{\mathrm{F}} \mathrm{Ph}$, which serves to enhance reactivity toward nucleophiles and to discriminate between the two double bonds of COD.

DFT computations were utilized to evaluate the various possible isomers of $10 \mathrm{Me}$ in order to assess their relative thermodynamic stabilities (Figure 6 and Tables 3 and 4). Four isomeric minima were obtained with the oxygen on the OMe group in various locations, as defined by its position relative to the $\mathrm{Pt}-\mathrm{O} / \mathrm{N}$ bonds (cis and trans) and the $\mathrm{CF}_{3}$ group (syn and anti). It was assumed, and test calculations supported this assumption, that methoxide addition would occur from the exo face of the COD. Table 3 summarizes the calculated relative free energies of the isomers, in kcal $\mathrm{mol}^{-1}$, for full QM/MM chemical models. Calculated electronic energies and enthalpies of formation show similar trends.

The isomer predicted to be most stable matches the experimentally observed structure; it is $\sim 5 \mathrm{kcal} \mathrm{mol}^{-1}$ lower in energy than the next lowest energy isomer. This result 
Table 4. Crystallographic Data for $\left.\left[\mathrm{Pt}^{\left({ }^{t} \mathrm{BA}\right.}{ }^{\mathrm{F}} \mathrm{Ph}\right)(\mathrm{COD})\right]$, $\left[\mathrm{Pt}\left({ }^{t} \mathrm{BA}{ }^{\mathrm{F} P h}\right)(\mathrm{COD})\right]\left(\mathrm{PF}_{6}\right) \cdot$ Acetone, $\left[\mathrm{Pt}\left({ }^{t} \mathrm{BA}{ }^{\mathrm{F}} \mathrm{Ph}\right)\left(\mathrm{C}_{8} \mathrm{H}_{12} \mathrm{OMe}\right)\right]$, and $\mathrm{Cp}_{2} \mathrm{Co}\left[\mathrm{Pt}\left({ }^{t} \mathrm{BA}{ }^{\mathrm{F}} \mathrm{Ph}\right)\left(\mathrm{C}_{8} \mathrm{H}_{12} \mathrm{OMe}\right)\right]$

\begin{tabular}{|c|c|c|c|c|}
\hline empirical formula & $\mathrm{C}_{29} \mathrm{H}_{36} \mathrm{~F}_{3} \mathrm{NOPt}$ & $\mathrm{C}_{32} \mathrm{H}_{42} \mathrm{~F}_{9} \mathrm{NO}_{2} \mathrm{PPt}$ & $\mathrm{C}_{30} \mathrm{H}_{39} \mathrm{~F}_{3} \mathrm{NO}_{2} \mathrm{Pt}$ & $\mathrm{C}_{40} \mathrm{H}_{49} \mathrm{CoF}_{3} \mathrm{O}_{2} \mathrm{Pt}$ \\
\hline formula weight & 666.68 & 869.73 & 697.71 & 886.82 \\
\hline temperature $(\mathrm{K})$ & $297(2)$ & $297(2)$ & 193(2) & 193(2) \\
\hline wavelength $(\AA)$ & 0.71073 & 0.71073 & 0.71073 & 0.71073 \\
\hline space group & $P 2_{1} / n$ & $P \overline{1}$ & $P 2_{1} / c$ & $P 2_{1} / n$ \\
\hline$a(\AA)$ & $12.6949(13)$ & $10.0548(3)$ & $11.6855(6)$ & $19.758(2)$ \\
\hline$b(\AA)$ & $20.1797(17)$ & $11.6944(3)$ & $20.0618(10)$ & 11.9094(13) \\
\hline$c(\AA)$ & $21.209(2)$ & $15.6582(4)$ & $24.0812(13)$ & $32.082(3)$ \\
\hline$\gamma\left({ }^{\circ}\right)$ & 90 & $107.526(2)$ & 90 & 90 \\
\hline volume $\left(\AA^{3}\right)$ & $5409.7(9)$ & $1752.29(8)$ & $5637.6(5)$ & $7437.8(14)$ \\
\hline$Z$ & 8 & 2 & 8 & 8 \\
\hline$\rho_{\text {calcd }}\left(\mathrm{Mg} / \mathrm{m}^{3}\right)$ & 1.637 & 1.648 & 1.644 & 1.584 \\
\hline$\mu(\operatorname{Mo~K\alpha })\left(\mathrm{mm}^{-1}\right)$ & 5.229 & 4.126 & 5.025 & 4.253 \\
\hline$F(000)$ & 2640 & 862 & 2776 & 3552 \\
\hline $\max$ and min transmission & 0.9016 and 0.4299 & 0.5135 and 0.3326 & 0.9062 and 0.3049 & 0.8832 and 0.7863 \\
\hline data/restraints/parameters & $10083 / 618 / 742$ & $10277 / 1163 / 592$ & $10577 / 0 / 681$ & $13517 / 907 / 899$ \\
\hline goodness of fit on $F^{2}$ & 1.079 & 1.026 & 0.998 & 0.984 \\
\hline \multirow[t]{2}{*}{ final $R$ indices (obsd data) } & $\mathrm{R} 1=0.0573$ & $\mathrm{R} 1=0.0247$ & $\mathrm{R} 1=0.0541$ & $\mathrm{R} 1=0.0673$ \\
\hline & $\mathrm{wR} 2=0.1073$ & $w \mathrm{R} 2=0.0604$ & $\mathrm{wR} 2=0.0952$ & $\mathrm{wR} 2=0.1028$ \\
\hline \multirow[t]{2}{*}{$R$ indices (all data) } & $\mathrm{R} 1=0.1494$ & $\mathrm{R} 1=0.0322$ & $\mathrm{R} 1=0.1547$ & $\mathrm{R} 1=0.1948$ \\
\hline & $\mathrm{wR} 2=0.1439$ & $\mathrm{wR} 2=0.0634$ & $\mathrm{wR} 2=0.1317$ & $\mathrm{wR} 2=0.1386$ \\
\hline largest diff peak and hole $\left(\mathrm{e} \cdot \AA^{-3}\right)$ & 2.911 and -1.320 & 0.792 and -0.470 & 1.664 and -1.813 & 1.317 and -1.564 \\
\hline
\end{tabular}

supports the inference that the observed methoxide addition product, $1 \mathrm{OMe}$, is thermodynamically controlled. Whereas deconvolution of the overall QM/MM energy into QM (electronic) and $\mathrm{MM}$ (steric) components is not without ambiguity, analysis of the separate QM and MM energies implies that the preference for isomer $\mathbf{A}$ over the other isomers is both steric (A versus $\mathbf{B}$ and $\mathbf{C}$ ) and electronic (A versus $\mathbf{D}$ ) in origin.

Previous calculations indicated that the susceptibility of coordinated alkenes toward nucleophilic addition is governed by charge, concluding that cationic complexes are required to promote reactions. Senn calculated a larger activation barrier for the nucleophilic attack of ammonia on the neutral complex, $\left[\mathrm{Rh}\left(\mathrm{PH}_{3}\right)_{2} \mathrm{Cl}\left(\mathrm{CH}_{2}=\mathrm{CH}_{2}\right)\right]\left(\Delta E^{\ddagger}=147\right.$ $\mathrm{kJ} / \mathrm{mol})$, than the cationic complex, $\left[\mathrm{Pd}\left(\mathrm{PH}_{3}\right)_{2} \mathrm{Cl}\left(\mathrm{CH}_{2}=\right.\right.$ $\left.\left.\mathrm{CH}_{2}\right)\right]^{+}\left(\Delta E^{\ddagger}=17 \mathrm{~kJ} / \mathrm{mol}\right){ }^{25}$ Sakaki studied the effect of charge on the addition of ammonia to $\mathrm{Pd}$-ethylene complexes. The cationic complex, $\left[\mathrm{PdF}\left(\mathrm{NH}_{3}\right)_{2}\left(\mathrm{CH}_{2}=\mathrm{CH}_{2}\right)\right]^{+}$, had a low calculated energy of activation $\left(\Delta E^{\ddagger}=33 \mathrm{~kJ} / \mathrm{mol}\right)$, whereas the neutral and anionic derivatives, $\left[\mathrm{PdF}_{3}\left(\mathrm{CH}_{2}=\right.\right.$ $\left.\left.\mathrm{CH}_{2}\right)\right]^{-}$and $\left[\mathrm{PdF}_{2}\left(\mathrm{NH}_{3}\right)\left(\mathrm{CH}_{2}=\mathrm{CH}_{2}\right)\right]$, respectively, were strongly destabilized toward the addition. ${ }^{26}$ Hoffmann proposed that nucleophilic attack of metal alkene complexes proceeds through an olefin-slipped $\left(\eta^{2}\right.$ to $\left.\eta^{1}\right)$ transition state. ${ }^{27}$ Calculations show an increase of $15-20 \mathrm{~cm}^{-1}$ in $\nu_{\mathrm{C}=\mathrm{C}}$ upon oxidation of $\mathbf{1}$ to $\mathbf{1}^{+}$, resulting from a decrease in backbonding in $\mathbf{1}^{+}$versus $\mathbf{1}$, which would facilitate olefin slippage.

(25) Senn, H. M.; Bloechl, P. E.; Togni, A. J. Am. Chem. Soc. 2000, 122, 4098-4107.

(26) Sakaki, S.; Maruta, K.; Ohkubo, K. Inorg. Chem. 1987, 26, 24992505.

(27) Eisenstein, O.; Hoffmann, R. J. Am. Chem. Soc. 1981, 103, 43084320.
Hahn has reported a $\Delta v_{\mathrm{C}=\mathrm{C}}$ of $12 \mathrm{~cm}^{-1}$ between the cationic $\left[\mathrm{Rh}(\mathrm{PNP})\left(\mathrm{CH}_{2}=\mathrm{CHPh}\right)\right]^{+}$and the dicationic $[\mathrm{Pd}(\mathrm{PNP})-$ $\left(\mathrm{CH}_{2}=\mathrm{CHPh}\right]^{2+}(\mathrm{PNP}=2,6$-bis(diphenylphosphanylmethyl)pyridine). ${ }^{28}$

\section{Conclusions}

The mild and reversible oxidation potentials of the amidophenolate complexes versus the related catecholate complexes clearly demonstrate the advantages of the amidophenolate ligand for organometallic chemistry and its potential for tunable organometallic catalysis. The $\mathrm{N}$ substituted amidophenolate ligand was utilized in the isolation of a pair of metal alkene complexes in which the redoxactive ligand is in two different oxidation states. Complexes $\mathbf{1}$ and $\mathbf{1}^{+}$were amenable to full spectroscopic and crystallographic characterization.

The susceptibility of coordinated olefins to nucleophilic attack is the basis for a variety of transformations, some of which are useful in organic synthesis. ${ }^{22}$ The electrophilic activation of alkenes is of increasing interest. ${ }^{26,28,29}$ The greater electrophilicity of cationic versus neutral platinum olefin complexes has been well-documented, especially by Natile and co-workers. ${ }^{28-30}$ The redox-active character of the amidophenolate allowed us to "turn on" the electrophi-

(28) Hahn, C. Chem.-Eur. J. 2004, 10, 5888-5899.

(29) Chianese, A. R.; Lee, S. J.; Gagné, M. R. Angew. Chem., Int. Ed. 2007, 46, 4042-4059.

(30) (a) Fanizzi, F. P.; Intini, F. P.; Maresca, L.; Natile, G.; Gasparrini, F. J. Chem. Soc., Dalton Trans. 1990, 1019-1022. (b) Maresca, L.; Natile, G. J. Chem. Soc., Chem. Commun. 1983, 40-41. (c) Pietropaolo, R.; Cusmano, F.; Rotondo, E.; Spadaro, A. J. Organomet. Chem. 1978, 155, 117-122. (d) Betts, M. S. J.; Harris, A.; Haszeldine, R. N.; Parish, R. V. J. Chem. Soc. A 1971, 3699-3705. (e) Maresca, L.; Natile, G. Comments Inorg. Chem. 1994, 16, 95-112. 
licity of the coordinated alkene. Whereas $\mathbf{1}$ is unreactive toward nucleophiles, the oxidized derivatives rapidly and stereospecifically add alkoxides at carbon. Although $[1 \mathrm{OMe}]^{-}$proved sufficiently stable to characterize, 1 exhibited no reactivity toward $\mathrm{NaOMe}$. Thus, the electrophilic enhancement by ligand-centered oxidation was required. Summarizing, the present work demonstrates the influence of redox poise of non-innocent ligands is sufficient to induce the reactivity of alkene ligands. Further studies involving monoalkenes would be of interest.

\section{Experimental Section}

Reactions and manipulations were performed under a nitrogen atmosphere using standard Schlenk line techniques. Solvents were dried and deoxygenated prior to use. The compounds $\mathrm{H}_{2}{ }^{t} \mathrm{BA}^{\mathrm{F}} \mathrm{Ph},{ }^{18}$ $\mathrm{PtCl}_{2}(\mathrm{COD})$, and $\mathrm{PtCl}_{2}(\mathrm{nbd})^{31}$ were prepared according to standard methods. Elemental analyses were conducted by the School of Chemical Sciences Microanalytical Laboratory. ${ }^{1} \mathrm{H}$ NMR spectra were acquired on a Varian Unity 500 instrument. Cyclic voltammetry was performed on a BAS CV-50W voltammetric analyzer. The following conditions were employed: $0.1 \mathrm{M} \mathrm{NBu}_{4} \mathrm{PF}_{6}$ as the supporting electrolyte, glassy carbon as the working electrode, $\mathrm{Ag} /$ $\mathrm{AgCl}$ in saturated $\mathrm{KCl}$ as the reference electrode, and $\mathrm{Pt}$ wire as the counter electrode. X-band EPR spectra were collected on a Varian E-122 spectrometer. Samples were prepared as $1 \mathrm{mM}$ solutions in 1:1 $\mathrm{CH}_{2} \mathrm{Cl}_{2}$ /toluene. Variable-temperature spectra were recorded using an E-257 variable-temperature accessory with liquid nitrogen as a coolant. The magnetic fields were calibrated with a Varian NMR Gauss meter, and the microwave frequency was measured with an EIP frequency meter. EPR spectra were simulated using SIMPOW software. ${ }^{32}$

$\mathbf{P t}\left({ }^{t} \mathbf{B A}{ }^{\mathrm{F}} \mathbf{P h}\right)(\mathbf{C O D})$, 1. A solution of $93 \mathrm{mg}(1.7 \mathrm{mmol})$ of $\mathrm{NaOMe}$ in $8 \mathrm{~mL}$ of $\mathrm{MeOH}$ was added dropwise to a stirring solution of $315 \mathrm{mg}(0.86 \mathrm{mmol})$ of $\mathrm{H}_{2}{ }^{t} \mathrm{BA}{ }^{\mathrm{F}} \mathrm{Ph}$ in $8 \mathrm{~mL}$ of $\mathrm{MeOH}$. The sodium salt of the ligand was then added to a solution of $323 \mathrm{mg}$ (0.86 mmol) of $\mathrm{Pt}(\mathrm{COD}) \mathrm{Cl}_{2}$ in $35 \mathrm{~mL}$ of $\mathrm{CH}_{2} \mathrm{Cl}_{2}$. The resulting orange solution was stirred for $2 \mathrm{~h}$, and the solvent was removed under vacuum. The orange product was extracted into $\sim 30 \mathrm{~mL}$ of $\mathrm{CH}_{2} \mathrm{Cl}_{2}$. The solvent was removed under vacuum to afford a bright orange solid. Yield: $545 \mathrm{mg}(95 \%) .{ }^{1} \mathrm{H}$ NMR $\left(\left(\mathrm{CD}_{3}\right)_{2} \mathrm{CO}\right): \delta 1.067$ (s, 9H, $\left.\mathrm{CH}_{3}\right), 1.413\left(\mathrm{~s}, 9 \mathrm{H}, \mathrm{CH}_{3}\right), 2.224-2.700\left(\mathrm{~m}, 8 \mathrm{H}, \mathrm{CH}_{2}\right), 4.104$ $(\mathrm{m}, 1 \mathrm{H}, \mathrm{CH}), 4.370(\mathrm{~m}, 1 \mathrm{H}, \mathrm{CH}), 5.293(\mathrm{~m}, 2 \mathrm{H}, \mathrm{CH}), 5.774(\mathrm{~d}$, $1 \mathrm{H}, \mathrm{CH}), 6.506(\mathrm{~d}, 1 \mathrm{H}, \mathrm{CH}), 7.258(\mathrm{~d}, 1 \mathrm{H}, \mathrm{CH}), 7.435(\mathrm{t}, 1 \mathrm{H}, \mathrm{CH})$, $7.72(\mathrm{t}, 1 \mathrm{H}, \mathrm{CH}), 7.828(\mathrm{~d}, 1 \mathrm{H}, \mathrm{CH})$. FD-MS $(\mathrm{m} / \mathrm{z}): 666\left\{\left[\mathrm{Pt}^{\mathrm{C}} \mathrm{BAA}^{\mathrm{F}}-\right.\right.$ $\mathrm{Ph})(\mathrm{COD})]^{+}$\}. Anal. Calcd for $\mathrm{C}_{29} \mathrm{H}_{36} \mathrm{~F}_{3} \mathrm{NOPt}$ (Found): $\mathrm{C} 52.22$ (51.83), H 5.45 (5.59), N 2.17 (2.10). Crystals were grown at room temperature by slow evaporation of solvent from an acetone/ methanol solution under an atmosphere of $\mathrm{N}_{2}$.

$\left[\mathbf{P t}\left({ }^{t} \mathbf{B A}^{\mathrm{F}} \mathbf{P h}\right)(\mathbf{C O D})\right] \mathbf{P F}_{6},[1] \mathbf{P F}_{6}$. A solution of $69 \mathrm{mg}(0.27$ mmol) of $\mathrm{AgPF}_{6}$ in $10 \mathrm{~mL}$ of THF was added dropwise to a stirring solution of $182 \mathrm{mg}(0.27 \mathrm{mmol})$ of $\mathbf{1}$ in $10 \mathrm{~mL}$ of THF. The resulting dark orange solution and metallic precipitate were stirred for $2 \mathrm{~h}$. The mixture was filtered, and the solvent was removed under vacuum. The orange solids were washed with $\sim 15 \mathrm{~mL}$ of hexanes. The dark orange product was extracted into $\mathrm{MeOH}$, and, again, the solvent was removed under vacuum. Yield: $182 \mathrm{mg}$ (83\%). Anal. Calcd for $\mathrm{C}_{29} \mathrm{H}_{36} \mathrm{~F}_{9} \mathrm{NOPPt}$ (Found): $\mathrm{C} 42.89$ (42.78), $\mathrm{H} 4.47$ (4.50), N 1.73 (1.79). Crystals were grown at room temperature by vapor diffusion of $\mathrm{Et}_{2} \mathrm{O}$ into an acetone solution of the compound.

(31) Drew, D.; Doyle, J. R. Inorg. Synth. 1990, 28, 346-349.

(32) Nilges, M. J.; Matteson, K.; Belford, R. L. SIMPOW6.
$\operatorname{Pt}^{t}\left(\mathbf{B A}^{\mathrm{F}} \mathbf{P h}\right)\left(\mathrm{C}_{8} \mathrm{H}_{12} \mathrm{OMe}\right)$, 1OMe. A solution of $116 \mathrm{mg}(0.14$ $\mathrm{mmol})$ of [1] $\mathrm{PF}_{6}$ and $8 \mathrm{mg}(0.14 \mathrm{mmol})$ of $\mathrm{NaOMe}$ in $20 \mathrm{~mL}$ of $\mathrm{MeOH}$ was allowed to stand for $1 \mathrm{~h}$. The solvent was removed in vacuo. The dark red material was extracted into $\sim 15 \mathrm{~mL}$ of hexanes. The solvent was removed under vacuum to give a dark red solid. Yield: $51 \mathrm{mg}(52 \%)$. FD-MS (m/z): $697\left\{\left[\mathrm{PtC}_{8} \mathrm{H}_{12} \mathrm{OMe}\left({ }^{\mathrm{B}} \mathrm{BA} \mathrm{F} \mathrm{Ph}\right)\right]\right\}$. Anal. Calcd for $\mathrm{C}_{30} \mathrm{H}_{39} \mathrm{~F}_{3} \mathrm{NO}_{2} \mathrm{Pt}$ (Found): C 51.62 (51.55), H 5.64 (5.68), N 2.01 (2.06). Crystals were grown at room temperature by slow evaporation of solvent from an acetone/methanol solution under $\mathrm{N}_{2}$. A stock solution of aqueous $\mathrm{HPF}_{6}(0.35 \mathrm{~mL}, 0.1 \mathrm{M})$ was added to $24 \mathrm{mg}(0.035 \mathrm{mmol})$ of $1 \mathrm{OMe}$ in $10 \mathrm{~mL}$ of MeCN. Immediately, the solution changed from red to orange. Mass spectrometry and UV-vis spectroscopy supported the assignment of the product as $1 \mathrm{PF}_{6}$.

$\mathbf{P t}\left({ }^{(} \mathbf{B} A^{\mathrm{F}} \mathbf{P h}\right)(\mathbf{n b d}), 2$. A flask was charged with $0.133 \mathrm{~g}(0.37$ mmol) of $\mathrm{PtCl}_{2}(\mathrm{nbd}), 0.136 \mathrm{~g}(0.37 \mathrm{mmol})$ of $\mathrm{H}_{2}{ }^{t} \mathrm{BA}{ }^{\mathrm{F}} \mathrm{Ph}$, and 50 $\mathrm{mL}$ of $\mathrm{CH}_{2} \mathrm{Cl}_{2}$. To the colorless solution was added $0.4 \mathrm{~mL}$ of $\mathrm{NEt}_{3}$, affording a vibrant orange solution. After the solution was stirred $2 \mathrm{~h}$, the solvent was removed under vacuum. The product was extracted into $100 \mathrm{~mL}$ of hexanes. The solvent was removed under vacuum to give a vibrant orange solid. Yield: $0.153 \mathrm{~g}(64 \%) .{ }^{1} \mathrm{H}$ NMR ( $\left.\left(\mathrm{CD}_{3}\right)_{2} \mathrm{CO}\right): \delta 1.077\left(\mathrm{~s}, 9 \mathrm{H}, \mathrm{CH}_{3}\right), 1.391\left(\mathrm{~s}, 9 \mathrm{H}, \mathrm{CH}_{3}\right), 2.834$ $\left(\mathrm{m}, 2 \mathrm{H}, \mathrm{CH}_{2}\right), 3.881(\mathrm{~m}, 2 \mathrm{H}, \mathrm{CH}), 4.1470(\mathrm{~m}, 2 \mathrm{H}, \mathrm{CH}), 4.749$ (m, $2 \mathrm{H}, \mathrm{CH}), 5.837(\mathrm{~d}, 1 \mathrm{H}, \mathrm{CH}), 6.506(\mathrm{~d}, 1 \mathrm{H}, \mathrm{CH}), 7.183(\mathrm{~d}, 1 \mathrm{H}$, $\mathrm{CH}), 7.406(\mathrm{t}, 1 \mathrm{H}, \mathrm{CH}), 7.664(\mathrm{t}, 1 \mathrm{H}, \mathrm{CH}), 7.749(\mathrm{~d}, 1 \mathrm{H}, \mathrm{CH})$. FD-MS $(\mathrm{m} / \mathrm{z}): 650 \quad\left\{\left[\mathrm{Pt}\left({ }^{t} \mathrm{BA}{ }^{\mathrm{F}} \mathrm{Ph}\right)(\mathrm{nbd})\right]^{+}\right\}$. Anal. Calcd for $\mathrm{C}_{28} \mathrm{H}_{32} \mathrm{~F}_{3} \mathrm{NOPt}$ (Found): C 51.67 (51.52), H 4.96 (5.02), N 2.15 (2.36).

$\left[\mathbf{P t}\left({ }^{(} \mathbf{B A}^{\mathrm{F}} \mathbf{P h}\right)(\mathbf{n b d})\right] \mathbf{P F}_{6},[2] \mathbf{P F}_{6}$. This complex was prepared analogously to $\left[\mathrm{Pt}\left({ }^{ } \mathrm{BA}{ }^{\mathrm{F}} \mathrm{Ph}\right)(\mathrm{COD})\right] \mathrm{PF}_{6}$. Yield: $(84 \%)$. Anal. Calcd for $\mathrm{C}_{28} \mathrm{H}_{32} \mathrm{~F}_{9} \mathrm{NOPPt}$ (Found): C 42.25 (41.99), H 4.06 (4.28), N 1.76 (1.97).

$\mathbf{P t}\left(\mathbf{O}_{2} \mathbf{C}_{6} \mathbf{H}_{2}{ }^{t} \mathbf{B u}_{2}\right)(\mathbf{C O D}), 3$. A flask was charged with $91 \mathrm{mg}$ (2 $\mathrm{mmol})$ of $\mathrm{NaOH}, 250 \mathrm{mg}(1 \mathrm{mmol})$ of ${ }^{t} \mathrm{Bu}_{2} \mathrm{C}_{6} \mathrm{H}_{2}(\mathrm{OH})_{2}$, and $30 \mathrm{~mL}$ of $\mathrm{MeOH}$. This solution was then added to a solution of $356 \mathrm{mg}$ (1 mmol) of $\mathrm{Pt}(\mathrm{COD}) \mathrm{Cl}_{2}$ in $60 \mathrm{~mL}$ of $\mathrm{CH}_{2} \mathrm{Cl}_{2}$. The resulting yellow solution was stirred for $3 \mathrm{~h}$, and the solvent was removed under vacuum. The orange product was extracted into $\sim 30 \mathrm{~mL}$ of $\mathrm{CH}_{2} \mathrm{Cl}_{2}$. Yield: $423 \mathrm{mg}(85 \%) .{ }^{1} \mathrm{H} \mathrm{NMR}\left(\mathrm{CDCl}_{3}\right): \delta 1.25\left(\mathrm{~s}, 9 \mathrm{H}, \mathrm{CH}_{3}\right), 1.36$ (s, 9H, $\left.\mathrm{CH}_{3}\right), 2.28\left(\mathrm{~m}, 4 \mathrm{H}, \mathrm{CH}_{2}\right), 2.62\left(\mathrm{~m}, 4 \mathrm{H}, \mathrm{CH}_{2}\right), 5.27(\mathrm{~m}, 4 \mathrm{H}$, $\mathrm{CH}), 6.61(\mathrm{~d}, 1 \mathrm{H}, \mathrm{CH}), 6.76(\mathrm{~d}, 1 \mathrm{H}, \mathrm{CH})$. FD-MS $(\mathrm{m} / \mathrm{z}): 523$ $\left\{\left[\mathrm{Pt}\left(\mathrm{O}_{2} \mathrm{C}_{6} \mathrm{H}_{2}{ }^{t} \mathrm{Bu}_{2}\right)(\mathrm{COD})\right]^{+}\right\}$. Anal. Calcd for $\mathrm{C}_{22} \mathrm{H}_{32} \mathrm{O}_{2} \mathrm{Pt}$ (Found): C 50.45 (50.25), H 6.16 (6.49), N 0.0 (0.21).

$\mathrm{Cp}_{2} \mathrm{Co}\left[\mathrm{Pt}\left({ }^{\mathrm{T}} \mathrm{BA}^{\mathrm{F}} \mathrm{Ph}\right)\left(\mathrm{C}_{8} \mathrm{H}_{12} \mathrm{OMe}\right)\right], \mathrm{Cp}_{2} \mathrm{Co}$ [10Me]. A solution of $6.9 \mathrm{mg}(0.01 \mathrm{mmol})$ of $1 \mathrm{OMe}$ and $1.9 \mathrm{mg}(0.01 \mathrm{mmol})$ of $\mathrm{Cp}_{2} \mathrm{Co}$ in $1 \mathrm{~mL}$ of $\mathrm{MeCN}$ was prepared. The resulting solution appeared yellow in color. When the solution was allowed to stand, single crystals appeared in the NMR tube.

Computational Methods. All computations were carried out with the Gaussian 03 software package. ${ }^{33}$ Equilibrium geometries and harmonic vibrational frequencies were determined using a QM/MM approach. ${ }^{34}$ The high level of theory was density functional theory (DFT) using the B3LYP hybrid density functional. The Stevens relativistic effective core potentials $(\mathrm{ECPs})^{35}$ and attendant triple- $\zeta$ valence basis sets were utilized to model the platinum atoms, and main group elements were modeled with the 6-31G(d) all-electron basis set. The low level of theory used the universal force field (UFF) ${ }^{36}$ All stationary points are confirmed minima on the potential energy surface. The QM partitioning included almost the entire complex, except 
for the $t$-butyl groups on ${ }^{t} \mathrm{BA}^{\mathrm{F}} \mathrm{Ph}$. Thermodynamic quantities were calculated at $298.15 \mathrm{~K}$ and $1 \mathrm{~atm}$.

Acknowledgment. This research was supported by the U.S. Department of Energy (DEFG02-90ER 14146). We thank Dr. Mark Nilges for assistance with EPR spectroscopy.

(33) Frisch, M. J.; Trucks, G. W.; Schlegel, H. B.; Scuseria, G. E.; Robb, M. A.; Cheeseman, J. R.; Montgomery, J. A., Jr.; Vreven, T.; Kudin, K. N.; Burant, J. C.; Millam, J. M.; Iyengar, S. S.; Tomasi, J.; Barone, V.; Mennucci, B.; Cossi, M.; Scalmani, G.; Rega, N.; Petersson, G. A.; Nakatsuji, H.; Hada, M.; Ehara, M.; Toyota, K.; Fukuda, R.; Hasegawa, J.; Ishida, M.; Nakajima, T.; Honda, Y.; Kitao, O.; Nakai, H.; Klene, M.; Li, X.; Knox, J. E.; Hratchian, H. P.; Cross, J. B.; Bakken, V.; Adamo, C.; Jaramillo, J.; Gomperts, R.; Stratmann, R. E.; Yazyev, O.; Austin, A. J.; Cammi, R.; Pomelli, C.; Ochterski, J. W.; Ayala, P. Y.; Morokuma, K.; Voth, G. A.; Salvador, P.; Dannenberg, J. J.; Zakrzewski, V. G.; Dapprich, S.; Daniels, A. D.; Strain, M. C.; Farkas, O.; Malick, D. K.; Rabuck, A. D.; Raghavachari, K.; Foresman, J. B.; Ortiz, J. V.; Cui, Q.; Baboul, A. G.; Clifford, S.; Cioslowski, J.; Stefanov, B. B.; Liu, G.; Liashenko, A.; Piskorz, P.; Komaromi, I.; Martin, R. L.; Fox, D. J.; Keith, T.; AlLaham, M. A.; Peng, C. Y.; Nanayakkara, A.; Challacombe, M.; Gill, P. M. W.; Johnson, B.; Chen, W.; Wong, M. W.; Gonzalez, C.; Pople, J. A. Gaussian 03, revision C.02; Gaussian, Inc.: Wallingford, CT, 2004.
The research at UNT was supported in part by a grant from the Offices of Basic Energy Sciences, U.S. Department of Energy (Grant No. DEFG02-03ER15387). Calculations employed the UNT computational chemistry resource, which is supported by the NSF through Grant No. CHE-0342824. Additional support was also provided by the University of North Texas Academic Computing Services for the use of the UNT Research Cluster.

Supporting Information Available: The CIF files for crystal structures and additional spectroscopic evidence. This material is available free of charge via the Internet at http://pubs.acs.org.

IC8017248

(34) (a) Svensson, M.; Humbel, S.; Froese, R. D. J.; Matsubara, T.; Sieber, S.; Morokuma, K. J. Phys. Chem. 1996, 100, 19357-19363. (b) Dapprich, S.; Komaromi, I.; Byun, K. S.; Morokuma, K.; Frisch, M. J. J. Mol. Struct.: THEOCHEM 1999, 462, 1-21.

(35) (a) Stevens, W. J.; Basch, H.; Krauss, M. J. Chem. Phys. 1984, 81, 6026-6033. (b) Stevens, W. J.; Krauss, M.; Basch, H.; Jasien, P. G. Can. J. Chem. 1992, 70, 612-613.

(36) Rappé, A. K.; Casewit, C. J.; Colwell, K. S.; Goddard, W. A., III; Skiff, W. M. J. Am. Chem. Soc. 1992, 114, 10024. 